\title{
Melanoma maligno metastático disseminado pela cavidade abdominal em equino tordilho
}

\author{
[a] Médico veterinário, Viamão, RS, Brasil \\ [b] Centro Universitário Ritter dos Reis (UniRitter), Porto Alegre, RS, Brasil \\ [c] Universidade Federal do Rio Grande do Sul (UFRGS), Porto Alegre, RS, Brasil
}

*Autor correspondente

e-mail: felipelinson14@hotmail.com

\section{Resumo}

O melanoma é uma neoplasia maligna que se origina dos melanócitos, que são as células que produzem melanina e são responsáveis pela pigmentação. Ocorre devido ao estímulo de formação de novos melanoblastos ou aumento excessivo de sua produção. Em equinos, esse tipo tumoral representa grande parte dos comprometimentos cutâneos, principalmente em animais de pelagem tordilha, porém não se observa predileção racial e sexual, sendo a idade considerada um agravante na malignidade. Em geral, são notados em equinos mais velhos, porém normalmente começam a se desenvolver em animais com 3 a 4 anos de idade. Esta afecção oncológica acomete principalmente as regiões de cauda e períneo, mas estes tumores podem se instalar em quaisquer outros lugares, inclusive nas regiões parotídea, auricular e ocular, e ocasionalmente se desenvolve em órgãos genitais, sendo que o curso clínico varia desde a formação de nódulos até a disseminação metastática. 0 diagnóstico preferencial é o histopatológico, e os tratamentos de escolha são a excisão cirúrgica e a crioterapia. No entanto, a recidiva é comum, pois embora a maioria seja benigna, variantes invasivas, algumas com potencial metastático, podem se desenvolver. 0 prognóstico é desfavorável, pois, em geral, o tumor é detectado tardiamente, quando já houve infiltração local ou formação de metástases. 0 objetivo do presente trabalho é relatar o caso de um equino macho, castrado, 18 anos de idade, sem raça definida (SRD) e de pelagem tordilha, localizado no município de Gravataí/RS, apresentando um nódulo firme, não ulcerado e não aderido, na região da cernelha, no lado esquerdo do corpo, com cerca de $10 \mathrm{~cm}$ de diâmetro. A fim de diagnosticá-lo, foi feita punção do material deste nódulo, que apresentava coloração vermelho escura e sem odor fétido, sendo encaminhado para exame no Laboratório de Patologia da Universidade Federal do Rio Grande do Sul (UFRGS). 0 resultado não apresentou nenhuma especificação 
diferente de coágulo sanguíneo. Dois meses depois, o tutor relatou apatia, perda de apetite e perda de peso progressiva do animal. Através do exame clínico, notou-se que o animal apresentava outros nódulos semelhantes ao inicial. Foi realizado hemograma e perfil bioquímico, cujo resultado demonstrou leve anemia, aumento de ureia e diminuição dos níveis de glicose, indicando a presença de disfunção hepática. Baseado na severidade da doença e na piora do seu prognóstico, o proprietário optou pela eutanásia do animal. Uma completa necropsia foi realizada, onde encontrou-se uma grande massa melanótica difusa pela cavidade abdominal, envolvendo grande parte fígado, mesentério, intestino e áreas multifocais no peritônio. Foram enviadas amostras do rim, fígado e dos fragmentos tumorais para análise histopatológica, e líquido peritoneal para análise citológica no Laboratório de Patologia da UFRGS. Os fragmentos tumorais foram descritos histologicamente com proliferação neoplásica maligna de células melanocíticas de maneira sólida, com moderado estroma de sustentação. As células apresentaram formato epitelioide, com citoplasma eosinofílico abundante, contendo em seu interior variável quantidade de melanina. Os núcleos eram ovalados com nucléolos evidentes e múltiplos. Anisocitose e anisocariose acentuadas e, em média, duas figuras de mitose por campo de maior aumento (400 x). Havia ainda, com frequência, células neoplásicas multinucleadas e com macrocariose. 0 fígado apresentava infiltrado neoplásico idêntico ao descrito anteriormente; e o rim, discreto infiltrado intersticial linfoplasmocitário. Os achados clínicos e patológicos permitiram concluir o diagnóstico de melanoma metastático. Conforme relatado em estudos anteriores, observou-se que juntamente com o fator pelagem, a idade do animal colabora com o surgimento de melanomas, visto que pelo aumento da expectativa de vida a população de equinos geriátricos tem aumentado significativamente.

Palavras-chave: Melanoma. Equino. Tordilho. 